DOI: 10.21005/pif.2021.46.B-05

\title{
SELECTION CRITERIA OF THERMO-INSULATING MATERIALS TO INSULATE WOODEN BUILDING FACILITIES
}

\section{KRYTERIA WYBORU MATERIAŁÓW TERMOIZOLACYJNYCH DO IZOLACJI OBIEKTÓW Z DREWNA}

\author{
Barbara Misztal \\ dr hab. inż. prof. PW \\ Author's Orcid number: 0000-0001-7811-1331
}

\author{
Anna Mielińska \\ mgr inż. arch. \\ Author's Orcid number: 0000-0001-6823-1751 \\ Politechnika Wrocławska \\ Wydział Architektury
}

\begin{abstract}
The article presents the structure of wood as a fibrous composite made up of cells susceptible to moisture absorption. Attention was paid to the impact of insulation materials on the durability of wood. The flow of moisture in materials such as wood and glass wool representing a group of porous and non-absorbing materials is shown. Microscopic pictures of pine and oak wood, wood fibre mats and glass wool are shown. The full construction of fibers of glass wool and other e. g. mineral wool, makes them extremely non-beneficial for warming partitions in buildings involving wood. Materials with a stable heat conductivity in terms of natural humidity changes in construction works were recommended.
\end{abstract}

Key words: insulation, wood, wooden buildings.

\section{STRESZCZENIE}

W artykule przedstawiono badania dotyczące struktury drewna jako kompozytu włóknistego zbudowanego z komórek podatnych na wchłanianie wilgoci. Zbadano wpływ materiałów izolacyjnych na trwałość drewna. Pokazano przepływ wilgoci w materiałach takich jak wełna drzewna i szklana reprezentujących grupę materiałów o włóknach porowatych i pełnych, nie nasiąkliwych. Przedstawiono zdjęcia mikroskopowe drewna sosnowego i dębowego, maty z włókien drzewnych i wełny szklanej. Pełna budowa włókien wełny szklanej i innych np. wełny mineralnej, powoduje, że są one wyjątkowo niekorzystne do ocieplania przegród w budynkach z udziałem drewna. Zalecono materiały o współczynniku przewodzenia ciepła stabilnym w zakresie naturalnych zmian wilgotności w obiektach budowlanych.

Słowa kluczowe: budynki drewniane, drewno, izolacja. 


\section{INTRODUCTION}

The economic pressure caused by the prices of energy brought about in Poland a dramatic increase in actions leading to the designing and production of the thermo-upgrading of buildings, including historical buildings and wooden buildings. The material solutions copy, most often, the building insulation methods used in the eighties of the $20^{\text {th }}$ century, developed for buildings of reinforced concrete. Those methods were developed in order to eliminate the defects of large-panel construction under the conditions of the emerging energetic crisis.

Brick buildings and wooden buildings were insulated since the second half of the $20^{\text {th }}$ century, like large-panel construction, using, most often, polystyrene and wool made of glass fibres and rock fibres. After years of operations, in buildings insulated using mats, e.g. made of mineral wool, biological corrosion efflorescence was noticed, in a huge variety of mould fungi. Those processes occurred on walls of reinforced concrete and, with a special intensity, in wooden building facilities and other facilities built using wood elements.

An essential role in the issues of the durability of building facilities made of wood play the conditions under which the wood is present. The wood located under the stable conditions of temperature and moisture has an almost unlimited durability. A confirmation of the high durability of wood is an exhibit shown in (Fig.1.), to be found in the International Maritime Museum in Hamburg (Internationales Maritimes Museum Hamburg, Hafen City).

a)

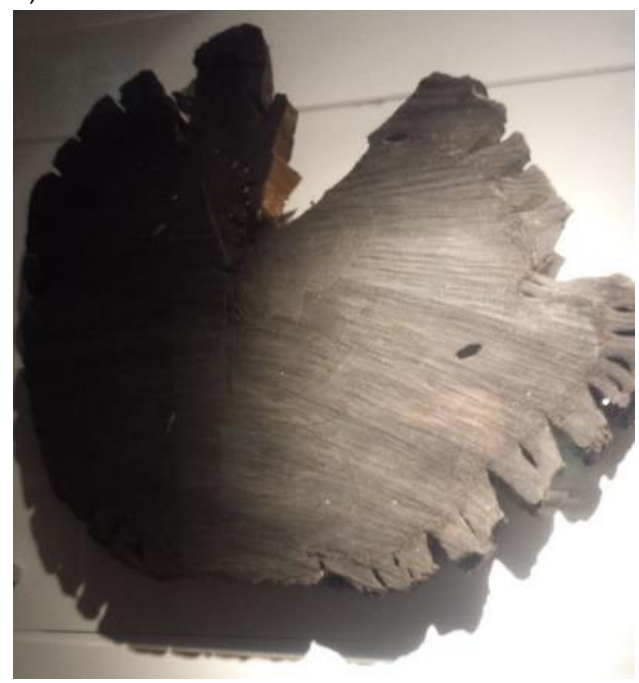

b)

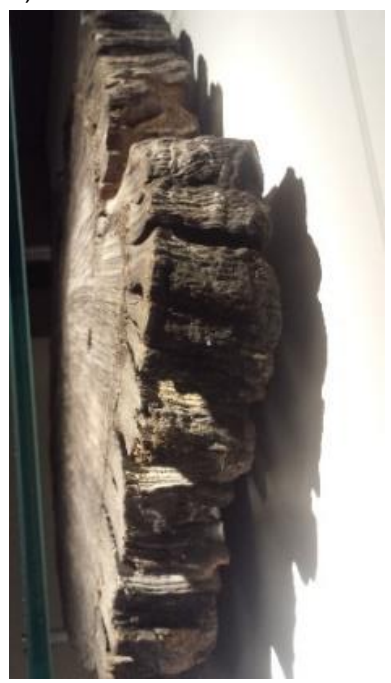

c)

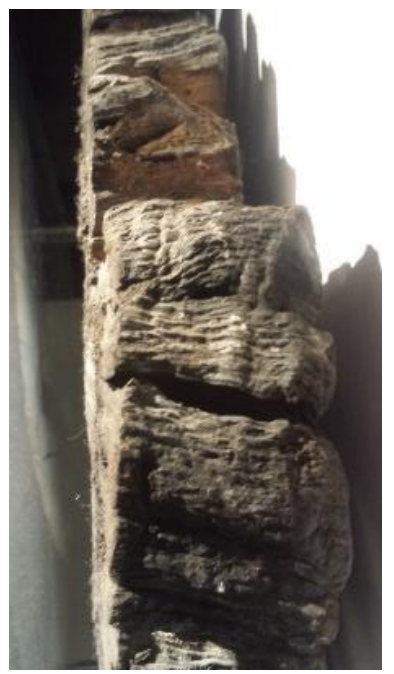

Fig. 1. View of the oldest wood cut out from an oak log found on the Earth, ca. 8000 years old, exhibited in the International Maritime Museum in Hamburg. Source: Photograph by Barbara Misztal, 2017.

Ryc. 1. Widok najstarszego znalezionego na Ziemi drewna wyciętego z kłody dębowej o wieku około 8000 lat, wyeksponowany w Międzynarodowym Muzeum Morskim w Hamburgu. Źródło: fot. Barbara Misztal, 2017.

The slice of wood shown was cut out of an oak wood log of ca. $6.0 \mathrm{~m}$ length retrieved from the Baltic Sea bottom, from a depth of ca. $8.00 \mathrm{~m}$. The testing conducted using the ${ }^{14} \mathrm{C}$ carbon isotope demonstrated that the wood had been lying under water for about eight thousand years. This is the oldest wooden element found on the Earth. 


\section{MICROSCOPIC EXAMINATIONS OF WOOD AND INSULATION MATS}

The modern fire-fighting requirements and those limiting heat losses in buildings coerce the use of various thermo-insulating materials, most often in the insulation of walls, ceilings and flat roofs. The most popular among them are mineral wool and glass wool, used due to the low price and great abundance. Since the selection of thermo-insulating materials influences directly the durability of wooden structures, a microscopic analysis of the structure of pine wood and oak wood representing the generally applied species used in the construction industry was performed, and the specimens made of wood wool mat and of glass fibres were employed, as representing materials of a porous and a solid structure of fibres.

The testing was performed at the Technological \& Conservation Laboratory of the Faculty of Architecture, Wroclaw University of Science and Technology. The specimens were prepared from pine wood and oak wood, saturated for 24 hours with demineralized water, afterwards they were cut mechanically and dried up naturally for 48 hours at the temperature of the Laboratory $-21^{\circ} \mathrm{C}$ on the average. The testing of wood and thermo-insulating materials was carried out in the Scanning Electron Microscope (SEM) model Tescan Vega II LSU, as well as using a digital KEYENCE microscope series VHX-7000.

\section{RESULTS}

Shown in (Fig.2a) is the fibrous structure of pine wood (Pinus strobus), shaped for around 300 million years of evolution). The early wood and the cells of late wood, were demonstrated in tangential section and cross section in (Fig.2a). (Fig.2b) exhibits, in tangential view, the layout of porous cells of the early wood and that of wood fibres of the late wood. Funnel cavities appear in pine wood, on the longitudinal walls of cells. The cavities have a funnel shape, arranged vertically and symmetrically on both the sides of the fibrous cell. Such a structure of pine wood brings produces that it is especially susceptible and absorbs moisture easily.

a)

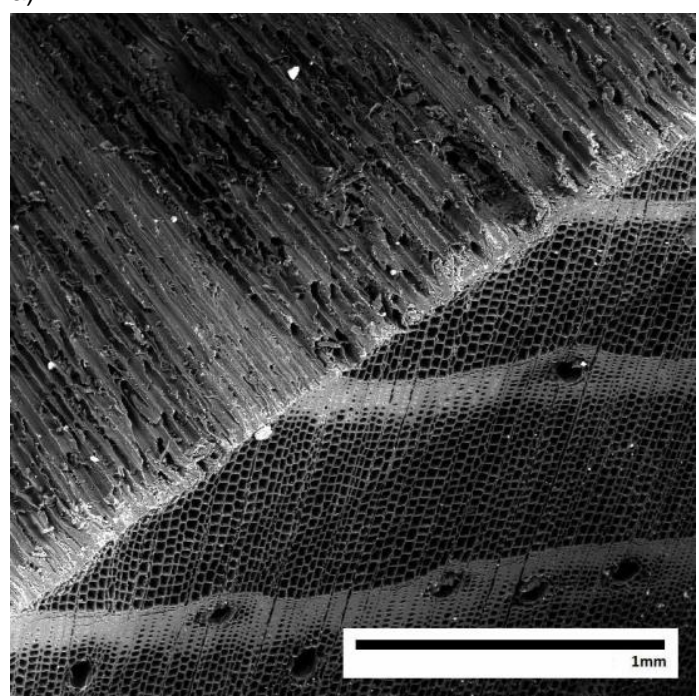

b)

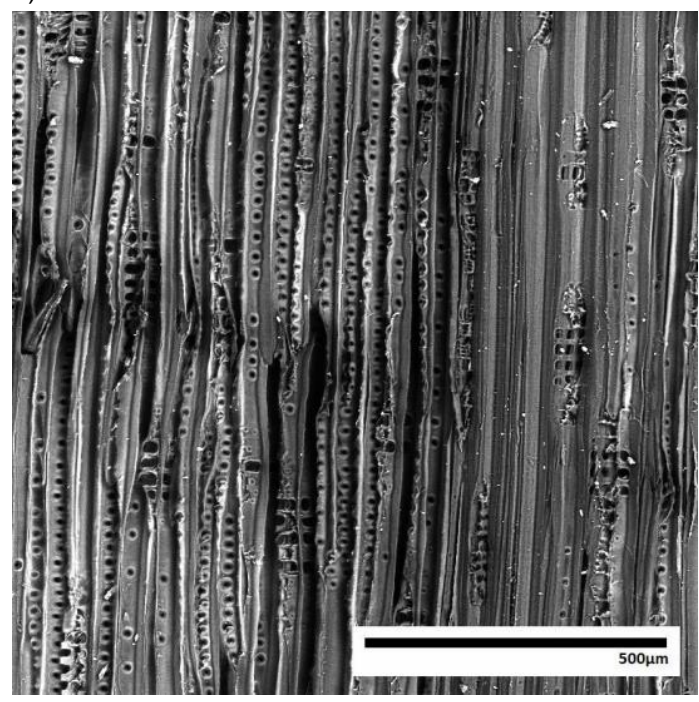

Fig. 2. Fibrous structure of pine wood (Pinus strobus): a) in a section with the view of the early wood and that of the late wood b) tangential view of porous parenchymatous cells and that of wood fibres of the late wood. Source: Photographs taken at the Technological \& Conservation Laboratory at the Faculty of Architecture, Wroclaw University of Science and Technology, by Ms. Anna Mielińska, MSc., Eng. of Architecture.

Ryc. 2. Włóknista budowa drewna sosny (Pinus strobus): a) w przekroju poprzecznym z widokiem komórek drewna wczesnego i późnego b) widok styczny porowatych komórek miękiszowych i włókien drzewnych drewna późnego, c) widok aksonometryczny badanej próbki drewna. Źródło: fotografie wykonane w Laboratorium Technologiczno - Konserwatorskim na Wydziale Architektury Politechniki Wrocławskiej przez p. mgr inż. arch. Annę Mielińską. 
Shown in (Fig. 3) is the fibrous structure of oak wood (Quercus robur) shaped during 150 million years of evolution). (Fig. 3a) demonstrates the parenchymatous cells of the early wood, of oval section and polygonal sections, as well as porous cellular walls. Especially well evident are holes appearing in the walls of conducting vessels (Fig. 3a). Flattened rectangular sections belong to the cells of the late wood, stiffening the composite.

a)

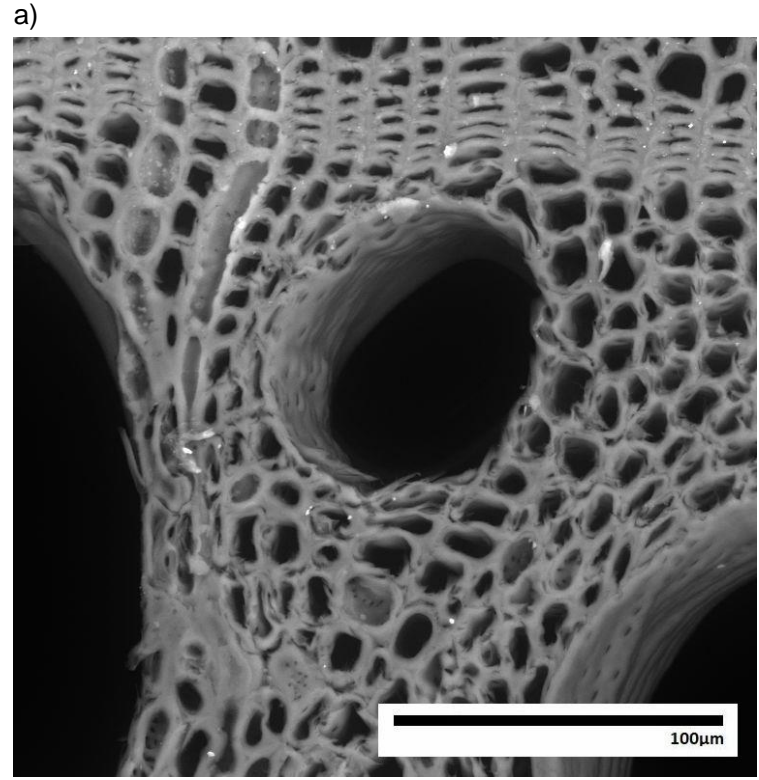

b)

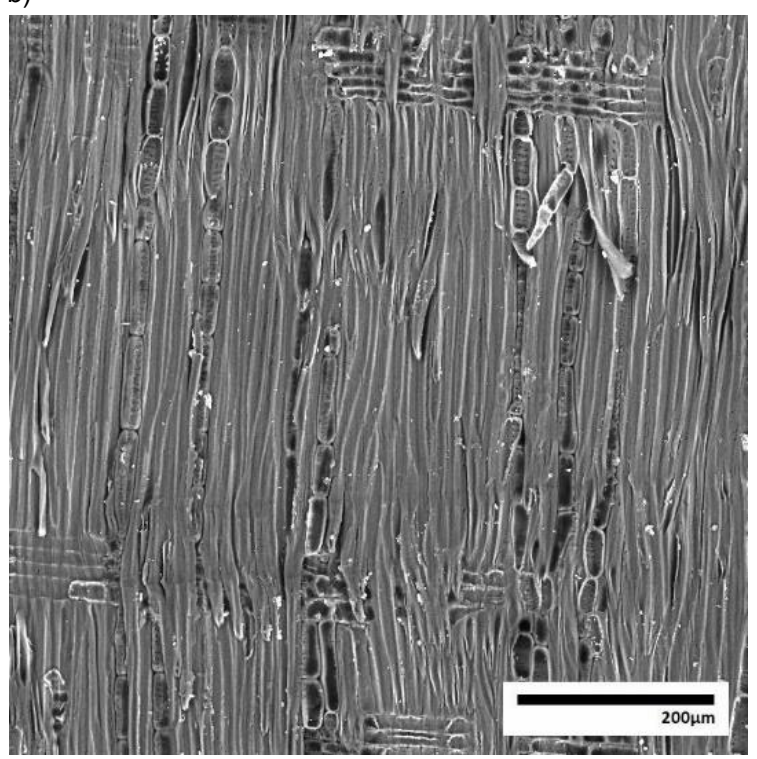

Fig. 3. Fibrous structure of oak wood (Quercus robur) shown in a) cross view, b) in tangential section. Source: Photographs taken at the Technological \& Conservation Laboratory at the Faculty of Architecture, Wroclaw University of Science and Technology, by Ms. Anna Mielińska, MSc., Eng. of Architecture.

Ryc. 3. Włóknista budowa drewna dębu (Quercus robur) pokazana w widoku a) poprzecznym, b) w przekroju stycznym. Źródło: Fotografie wykonane w Laboratorium Technologiczno - Konserwatorskim na Wydziale Architektury Politechniki Wrocławskiej przez p. mgr inż. arch. Annę Mielińską.

Shown in (Fig. 3b) is the layout of radial heat conducting vessels in the mass of fibrous cells. Massive fibres of the late wood arranged in bundles are also evident. The wood species presented differ in the porosity of cell walls of the late wood. Cavities in the walls of pine wood and holes in the walls of oak wood look differently. The perforation of walls is irregular in oak wood, over the whole circumference and length of the fibrous cell. The structure, layout and sizes of holes cause that the oak wood is less susceptible to moisture absorption.

Fibrous thermo-insulating materials belong to those presently generally applied in the multi-layer building partition walls combined with wood. For the analysis, wool from wood fibres, representing materials of a porous structure of fibres and glass wool as representing materials of a solid structure of fibres, not absorbing moisture, were selected. Fig. 4 presents the microscopic photographs of the insulation materials tested: mats of wood fibres and those of glass fibres.

Glass wool (like mineral wool) in microscopic magnification is a thin fibre, of a solid section, not absorbing moisture - (Fig. 4d). The principal difference between an insulation made of glass wool, and that of a wood mat with absorbable wood fibres - (Fig 4a, b), consists in the structure of fibres of the said materials. In the insulation made of wood fibres moisture is absorbed with the whole volume of fibres. Porous fibres are hygroscopic. Upon soaking of the insulation, fibres absorb moisture in the first order. This property of wood chips and other porous fibres appear in various thermo-insulating materials brings about that in the case of multi-layer partition walls insulated using 
them the removal of water steam, like its absorption, will be decidedly more effective than in materials built of non-hygroscopic fibres.

If moisture does not get absorbed into the fibres of the thermo-insulating material, it will accumulate initially on the surface, afterwards it will fall gravitationally, accumulate in the pores between the fibres, and finally penetrate into the mass of wood.

a)

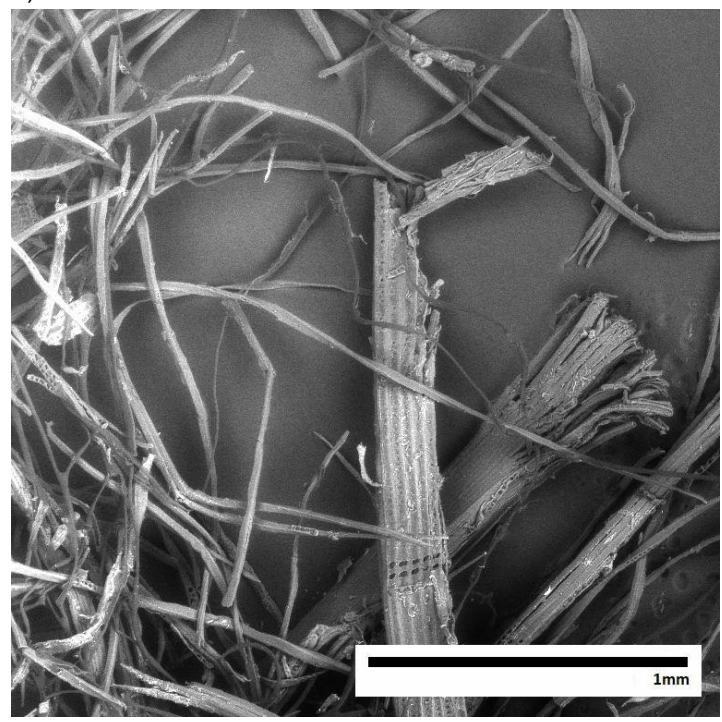

c)

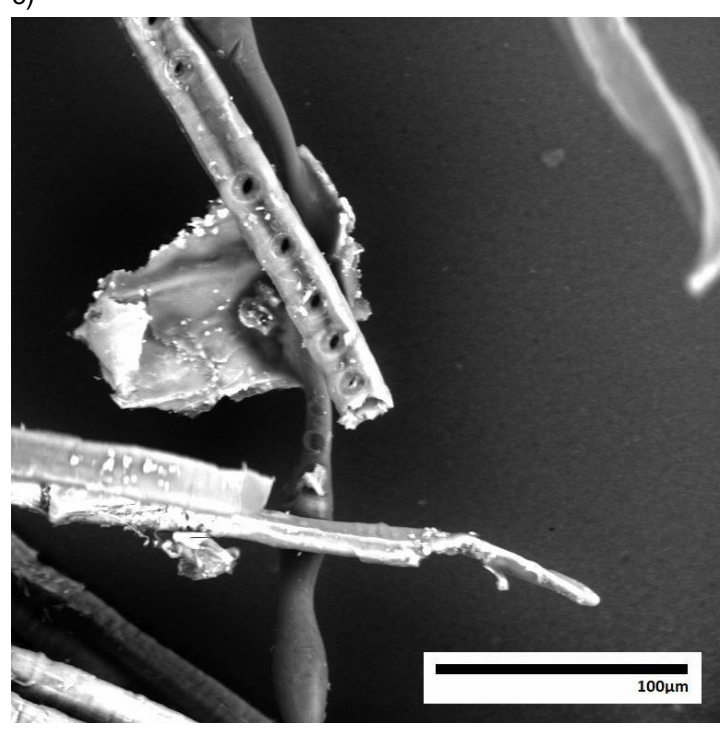

b)

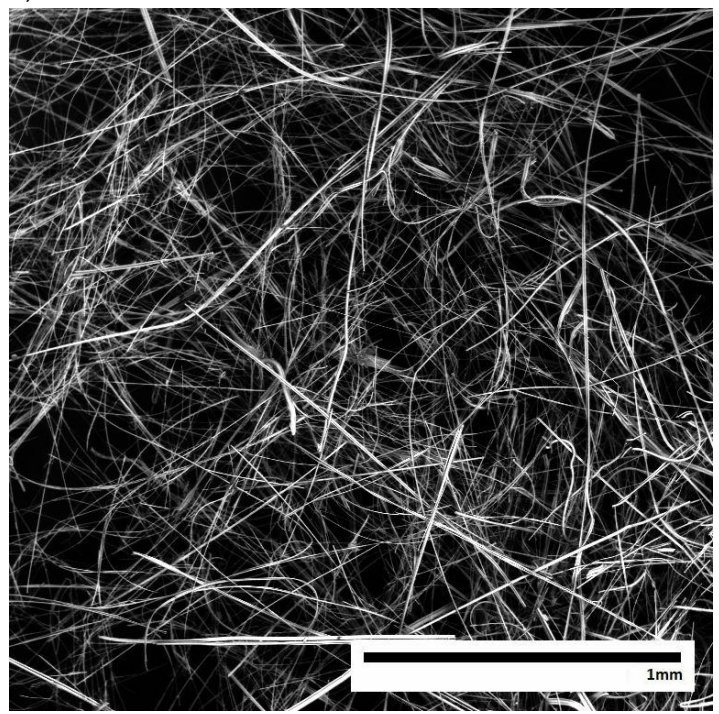

d)

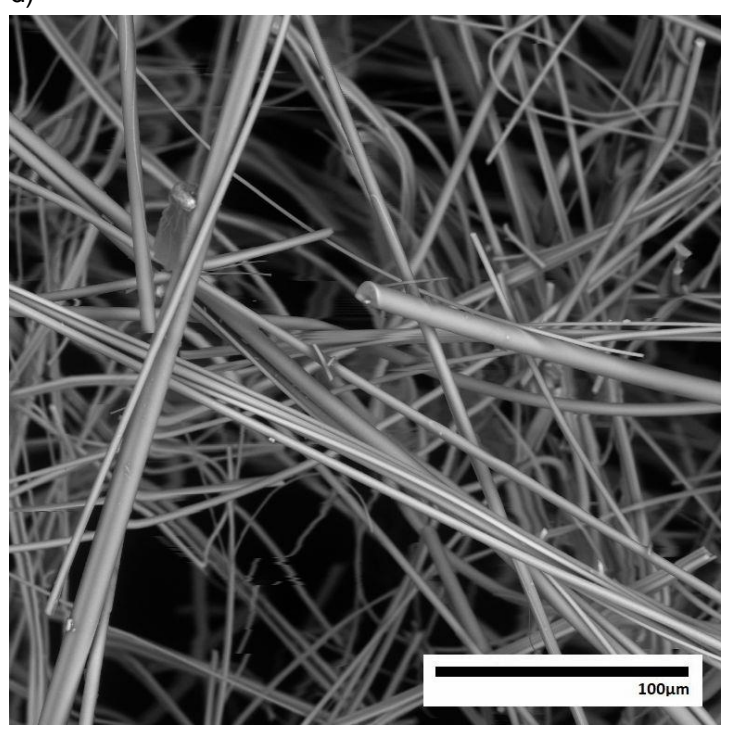

Fig. 4. Insulating materials generally applied in the construction industry, a) view of a mat made of wood wool, b) view of a mat made of glass wool, c) view of porous wood fibres, d) view of fibres of glass wool of a solid section (no capacity to absorb moisture). Source: Photographs taken at the Technological \& Conservation Laboratory at the Faculty of Architecture, Wroclaw University of Science and Technology, by Ms. Anna Mielińska, MSc., Eng. of Architecture.

Ryc. 4. Materiały izolacyjne stosowane powszechnie $w$ budownictwie, a) widok maty $z$ wełny drzewnej, b) widok maty z waty szklanej, c) widok porowatych włókien drzewnych, d) widok włókien z maty szklanej o pełnym przekroju, (brak możliwości wchłaniania wilgoci). Żródło: Fotografie wykonane w Laboratorium Technologiczno - Konserwatorskim na Wydziale Architektury Politechniki Wrocławskiej przez p. mgr inż. arch. Annę Mielińską. 
a)

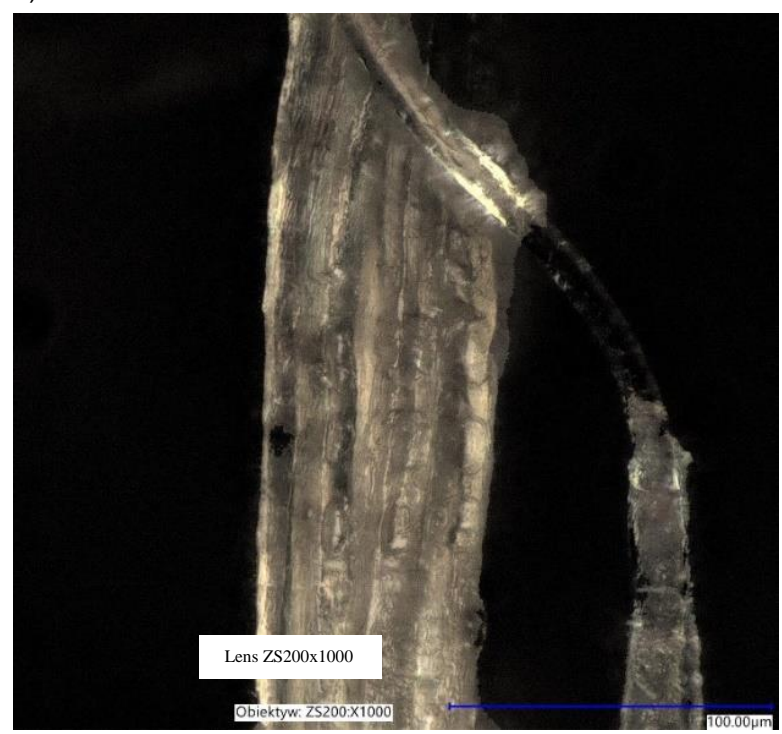

b)

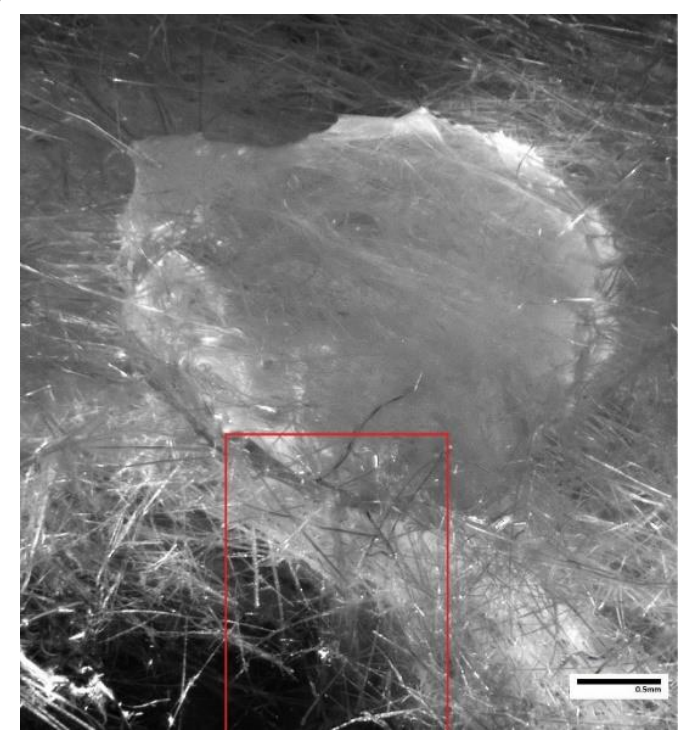

Fig. 5. Illustration of the moisture absorption mechanism in the fibres collected from insulating materials: a) wood wool, visible water drops sustained in the fibre, in longitudinal section, b) view of glass wool with a water drop. The stream of the gravitational water falling is marked with a red rectangle. Source: Photographs taken with the KEYENCE microscope by Mr. Mateusz Skoczylas, MSc., Eng.

Ryc. 5. Ilustracja mechanizmu pochłaniania wilgoci w włóknach pobranych z mat izolacyjnych: a) wełny drzewnej, w przekroju podłużnym widoczne krople wody utrzymujace się w naczyniu, b) widok waty szklanej z kroplą wody. Strugę grawitacyjnego opadania wody zaznaczono czerwonym prostokatem. Żródło: Fotografie wykonano mikroskopem KEYENCE przez p. mgr inż. Mateusza Skoczylasa

The mechanism of water dispersal from a drop located in a wood mat and a glass mat is shown in (Fig. 5a, b). A fibre from wood wool moistened by a drop of water is demonstrated in (Fig. 5a) in longitudinal section. The absorbed water is visible in form of several drops. Water does not appear in the surroundings of the fibre. (Fig. 5b) demonstrates water remaining on the fibres from a glass mat. The stream of water falling gravitationally is marked with a red rectangle. If water accumulates in pores between fibres, eliminating air, the properties of the material change. The material turns from an insulator into a conductor. Similar moistening processes follow in specimens made of mineral wool which is also built up of fibres of homogenous and solid sections. The water accumulating material in the vicinity of wood constitutes a threat to its durability since all destruction processes of wood start with its moistening of wood.

\section{DISCUSSION}

The impact of moistening, temperature and that of the protection technology factors on the durability of wood was examined by many researchers. In the paper (Bednarek Z., at all 2004) the methods and effects of interference with wood using salt preparations by the team of paper were described. The wood was examined after the vacuum and pressure impregnation at the temperatures of $20^{\circ} \mathrm{C}, 50^{\circ} \mathrm{C}, 100^{\circ} \mathrm{C}, 150^{\circ} \mathrm{C}, 200^{\circ} \mathrm{C}, 230^{\circ} \mathrm{C}$. The specimens were tested both statically and dynamically. In the static testing, the following testing was performed: bend test, compression test along fibres, compression test across fibres. In the dynamic testing the strength to dynamic bending and the impact resistance of wood were examined. It was proved that the use of vacuum and pressure impregnation methods using a salt preparation reduces the strength of specimens made of impregnated wood in relation to those of non-impregnated wood. The authors explain that this is related to the infringement of the structure of wood as a result of the interference using a water 
solution of salt, pressure variation and sub-pressure variation during the saturation with the impregnating substance.

In the doctoral dissertation (Jarosz M. 2020) the use of thermo-insulating materials in the thermomodernisation of antique building facilities made of wood in the region of the Sudeten Mountains was analysed. Multi-layer outside partition walls of buildings modernised using the insulating materials available on the market, including mineral wool, were examined. Various conditions and effects of their use were demonstrated. Despite a broad analysis, a criterion was not formulated according to which the selection of the thermo-insulation to warm up wooden building facilities can be made.

In the paper (Trochonowicz M. at all 2013) the variation of the value of the coefficient of heat conductivity $\lambda$ of thermo-insulating materials built into room interiors was analysed and calculated. The diagrams from the paper (Badger S. 2017) are quoted in (Fig. 7.)

a)

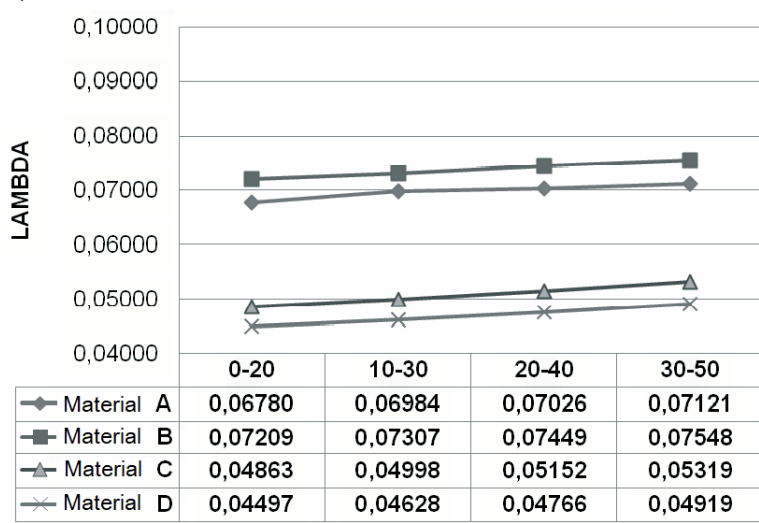

b)

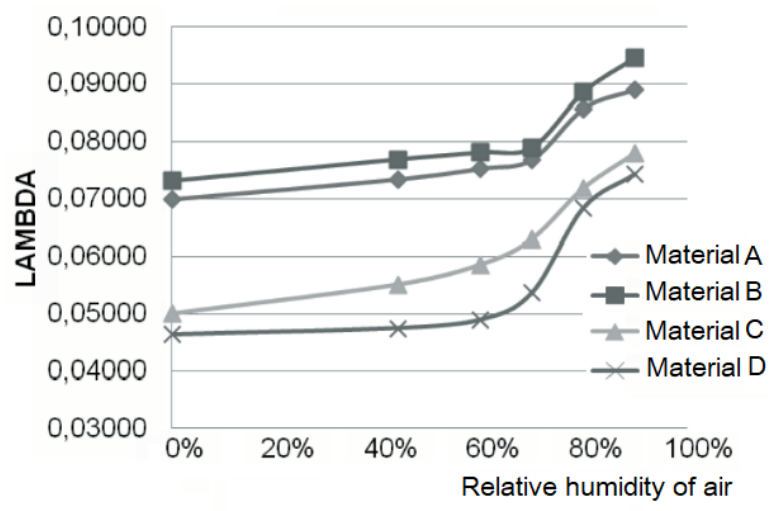

Fig. 6. Variation of the coefficient of heat conductivity depending on ambient temperature and humidity according to (Trochonowicz M. at all 2013), a) diagram of the dependence of the coefficient $\lambda$ on temperature b) diagram of the dependence of the coefficient $\lambda$ on the humidity of air for the materials being tested(Trochonowicz M. at all 2013).

Ryc. 6. Zmiana współczynnika przewodzenia ciepła w zależności od temperatury i wilgotności otoczeni wg ( Trochonowicz M. at all 2013) a) wykres zależności współczynnika $\lambda$ od temperatury b) wykres zależności współczynnika $\lambda$ od wilgotności powietrza dla badanych materiałów (Trochonowicz M. at all 2013).

It follows from the diagrams in Fig. 6 that as the temperature and the moistening of thermoinsulating materials rise, the coefficient of heat conductivity $\lambda$ increases.

The subject matter of the value of the coefficient of heat conductivity $\lambda$ jointly with the rise in the amount of water in the pores between fibres of thermo-insulating materials was dealt with by Badger S. and described in the paper (Badger S. 2017). In the paper attention was drawn to the fact that an insulation must be dry in order to be effective. The insulation specimens tested were made in form of plates and shown in Fig. 7. The specimens were subjected to the interference of steam through the exhibition of the surface of 8 inch $\times 8$ inch dimensions to the interference of water at $50^{\circ} \mathrm{C}$ temperature and the temperature difference of $\Delta \mathrm{T}=1^{\circ} \mathrm{C}$ on opposite surfaces. The specimens were not rotated during the testing. The thermal conductivity of the specimens was determined using the method described in the standard ASTM C518. 
a)

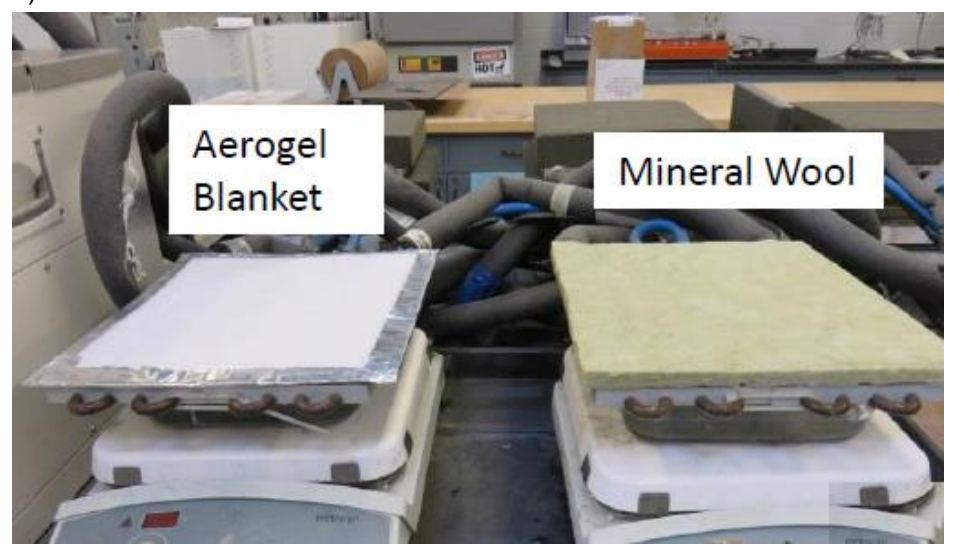

b)

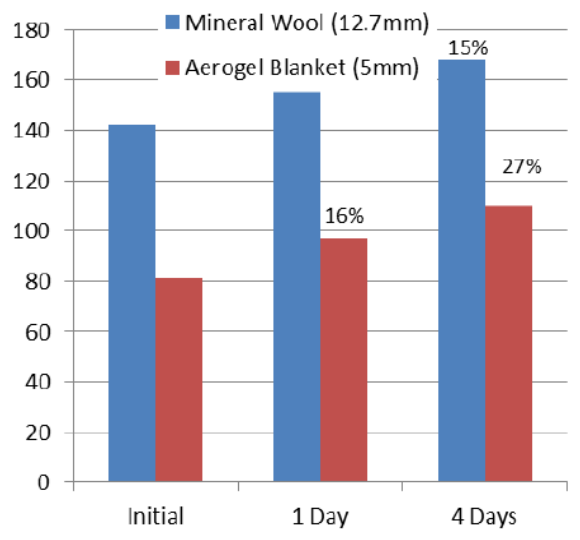

Fig. 7. Variation diagram of the coefficient of heat conductivity depending on the level of humidity: view of the materials being tested: aerogel blanket and mineral wool, b) percentage rise in mass and coefficient of heat conductivity in time. Source: (Tarkowski S., Krajewski J., 2002) [6]2017

Ryc. 7. Wykres zmian współczynnika przewodzenia ciepła w zależności od poziomu wilgotności: widok badanych materiałów: płytka z aerożelu i wełny mineralnej, b) procentowy wzrost współczynnika przewodzenia ciepła w czasie. Źródło: [6] 2017

As early as after four days there followed a considerable rise in the mass and the coefficient of heat conductivity of mineral wool, which is demonstrated in the diagram - Fig. 7b). If there followed a rise in the mass of mineral wool, then moisture accumulated in the pores between fibres since the fibres are not absorbable. In the mat, there occurred a decrease in the amount of the space filled up with air. Here, it is worth reminding that the coefficient of heat conductivity is illustrated by the rate $\lambda=0,025\left[\frac{W}{m \times K}\right]$, and that of water by the rate $\lambda=0,6\left[\frac{W}{m \times K}\right]$. The heat conductivity of water is almost twenty-four times (24-times) higher than the heat conductivity of air. A thermoinsulating material, of fibres absorbable as a result of moistening, turns from an insulator into a conductor. Heat losses in buildings insulated with mineral wool enlarge, and moisture liquefies and biological corrosion develops on the walls from the inside. The said processes are particularly detrimental for wood.

A consequence of the presence of water instead of air in the pores between fibers in mats made up of solid, non-hygroscopic fibres is a change in the insulating properties. As the coefficient of heat conductivity $\lambda$ increases, the thermal resistance of the material decreases $R=\frac{1}{\lambda}$ and the thermal insulation of the partition wall decreases.

\section{Moistened glass wool and mineral wool becomes a conductor, and not an insulator.}

In thermo-insulating materials made up of porous fibres the moisture absorbed by porous fibres does not produce a significant loss of the thermal properties of the insulation since the spaces between fibres filled up with air, and the continuous ventilation in the layer of insulation brings about the removal of moisture from the space between fibres. In each insulating material the value of the coefficient of heat conductivity $\lambda$ depends on the number of pores filled up with air. The higher is the number of pores with air between fibres, the lower is, that is, better is the coefficient $\lambda$, and the thermo-insulating material has a higher thermal resistance $\mathrm{R}$, and it is an insulator.

In the moistened insulating material, in the vicinity of nutrient, which wood is, there follows the development of biological corrosion. 
Biological corrosion causes sensor defects leading to weakening of wood fibres and a global reduction in the load capacity of wooden elements, as described in (Kowal Z., 1996 and Misztal B., in 2018)

The paper (Tarkowski S. at all. 2002) discusses the threats to health associated with the use of solid mineral fibres, in particular mineral insulation wool. In accordance with the EU Directive 98/98/EC, mineral wool has been classified as irritating in category 3. The paper (Tarkowski S. at all. 2002) does not discuss the so-called granulate of mineral wool, generally used in Poland to insulate flat roofs. This is a loose material, exceptionally toxic, of variable thermo-insulating properties. The so-called granulate of mineral wool is unfavourable, especially in the thermal insulation of wooden structures. To supplement the foregoing information, it should be added that since June 2000, in Germany, a ban has been applied on the turnover, production and use of bio-persistent mineral fibres in the thermal and acoustic insulation of buildings and in technical insulations (Tarkowski S. at all. 2002).

\section{CONCLUSIONS}

The structure of wood produces that the choice of thermo-insulating materials in the vicinity wood in building partition walls cannot be accidental.

Mineral wool or glass wool are made of raw materials advertised as natural. In contact with wood, this is not a sufficient circumstance. The use of an insulating material, retaining moisture, in the presence of wood is incorrect. Homogenous and non-porous glass fibres and mineral fibres have no capacity to absorb water. Moisture from the environment pushes out air from the space between fibres and fills them up, turning the insulating material in to a conducting one.

The porous structure of fibres, e.g. wood wool (Fig. 4a, c) and Fig. 5a produces that the material has the capacity of capillary pull-up, to accumulate moisture and to release it slowly jointly with a drop in the ambient moisture. With the continuous replacement of air in the multi-layer partition wall, the expulsion of the moisture excess between fibres and from fibres is effective due to the large evaporation surface of porous fibres. The use in the vicinity of wood of a thermo-insulation built up of fibres of a porous structure, absorbing moisture, earlier, before it penetrates into the wooden structural element is a necessary condition.

In insulating materials built up of porous fibres, water, in the first order, becomes absorbed by fibres - Fig. 5a, leaving the spaces between fibres filled up with air. Due to the capacity of the absorption of a certain portion by fibres, the pores between fibres are filled up with air, the mat retains its thermo-insulating properties, and the coefficient of heat conductivity $\lambda$ and the thermal resistance $\mathrm{R}$ of the insulating mat change insignificantly.

As a selection criterion of a thermo-insulating material located in the close vicinity of wood, recommended are materials of a stable coefficient of heat conductivity $\lambda$ within the interval of the natural variation of ambient moisture, in which building partition walls are located, having a share in wood. Neither mineral wool nor glass wool meet this criterion. 


\section{KRYTERIUM WYBORU MATERIAŁÓW TERMOIZOLACYJNYCH DO IZOLACJI OBIEKTÓW Z DREWNA}

\section{WSTĘP}

Ekonomiczny nacisk spowodowany cenami energii spowodował lawinowe zwiększanie działań prowadzących do projektowania i wykonywania termomodernizacji obiektów budowlanych, w tym budynków historycznych i drewnianych. Rozwiązania materiałowe kopiują najczęściej metody ocieplania budynków stosowane w latach osiemdziesiątych XX w., opracowane dla budynków żelbetowych. Metody te opracowano w celu wyeliminowania wad budownictwa wielkopłytowego w warunkach rozpoczynającego się kryzysu energetycznego.

Budynki murowane i drewniane ocieplano od drugiej połowy XX w., podobnie jak budownictwo wielkopłytowe, stosując najczęściej styropian i wełnę wykonaną z włókien szklanych lub kamiennych. Maty z włókien mineralnych stosuje się do dzisiaj z uwagi na ich stosunkowo dużą podaż i niską cenę. Po latach eksploatacji zauważono w budynkach, ocieplonych matami $\mathrm{np}$. z wełny mineralnej, wykwity korozji biologicznej w ogromnej różnorodności grzybów pleśniowych. Procesy te wystąpiły na ścianach żelbetowych, a ze szczególną intensywnością w obiektach drewnianych i innych zbudowanych z wykorzystaniem elementów z drewna.

Istotną rolę w zagadnieniach trwałości obiektów budowlanych z drewna odgrywają warunki w jakich znajduje się drewno. Drewno znajdujące w ustalonych warunkach temperatury i wilgotności posiada niemal nieograniczoną trwałość. Potwierdzeniem wysokiej trwałości drewna jest eksponat pokazany na ryc.1., znajdujący się w Międzynarodowym Muzeum Morskim w Hamburgu. (Internationales Maritimes Museum Hamburg, Hafen City).

Pokazany plaster drewna dębowego wycięto z kłody dębowej o długości około $6.0 \mathrm{~m}$ wydobytej $\mathrm{z}$ dna Bałtyku z głębokości około $8,00 \mathrm{~m}$. Testy prowadzone metodą izotopu węgla ${ }^{14} \mathrm{C}$ wykazały, że drewno leżało na dnie Bałtyku około osiem tysięcy lat. Jest to najstarszy element drewniany znaleziony na Ziemi.

\section{BADANIA MIKROSKOPOWE DREWNA I MAT IZOLACYJNYCH}

Współczesne wymogi przeciw pożarowe i ograniczające straty ciepła w budynkach wymuszają stosowanie różnorodnych materiałów termoizolacyjnych, najczęściej w ocieplaniu ścian, stropów i stropodachów. Najbardziej popularne z nich to wełna mineralna i wata szklana, stosowane z powodu niskiej ceny i dużej podaży. Ponieważ dobór materiałów izolacyjnych ma bezpośredni wpływ na trwałość konstrukcji drewnianych, przeprowadzono mikroskopową analizę budowy drewna sosnowego i dębowego reprezentujących gatunki powszechnie stosowane $w$ budownictwie, oraz posłużono się próbkami z maty wełny drzewnej i włókien szklanych, jako reprezentujących materiały o porowatej i pełnej budowie włókien.

Badania przeprowadzono w Laboratorium Technologiczno-Konserwatorskim Wydziału Architektury Politechniki Wrocławskiej. Próbki przygotowano z drewna sosnowego i dębowego, nasączano przez $24 \mathrm{~h}$ w wodą demineralizowaną, a następnie cięto mechanicznie i osuszano naturalnie przez $48 \mathrm{~h} \mathrm{w}$ temperaturze laboratorium - średnio $21^{\circ} \mathrm{C}$. Badania drewna i materiałów termoizolacyjnych przeprowadzono w skaningowym mikroskopie elektronowym (SEM) Tescan Vega II LSU, oraz za pomocą mikroskopu cyfrowego KEYENCE seria VHX-7000.

\section{REZULTATY}

Na ryc. 2a pokazano, ukształtowaną przez około 300 milionów lat ewolucji budowę włóknistą drewna sosnowego (Pinus strobus). Drewno wczesne i komórki drewna późnego, pokazano w przekroju stycznym i poprzecznym na ryc. 2a. Na ryc. $2 b$ pokazano w widoku stycznym rozmieszczenie porowatych komórek drewna wczesnego i włókien drzewnych drewna późnego. W drewnie sosno- 
wym na ściankach podłużnych komórek występują lejkowate jamki. Jamki mają kształt lejkowaty, ułożone są pionowo i symetrycznie po obu stronach włóknistej komórki,. Taka budowa drewna sosnowego powoduje, że jest ono szczególnie podatne i łatwo wchłaniające wilgoć.

Na ryc. 3 pokazano ukształtowaną przez 150 milionów lat ewolucji budowę włóknistą drewna dębowego (Quercus robur). Na fotografiach widać komórki miękiszowe drewna wczesnego o wielokątnych przekrojach i porowatych ściankach komórkowych. Szczególnie dobrze widoczne są otwory w ściankach występują w naczyniach przewodzących - ryc. 3a). Spłaszczone przekroje prostokątne komórek należą do komórek drewna późnego, usztywniającego kompozyt. Ścianki komórek drewna wczesnego i naczyń są porowate, co umożliwia przepływ płynów. Rozmieszczenie otworów na ścianach podłużnych naczyń jest nieregularne i różni się od regularnego rozmieszczenia jamek w komórkach drewna iglastego. Miękiszowe komórki wczesnego drewna dębowego otaczają naczynia o wyróżniającej się w przekroju poprzecznym większą średnicą. Na ryc. 3b pokazano rozmieszczenie naczyń przewodzących w masie komórek miękiszowych w kierunku promieniowym. Widać także masywne włókna drewna późnego występujące w wiązkach.

W obu gatunkach włókna drzewne, charakteryzują się pierścieniowym upakowaniem i rozmieszczone są w masie porowatych komórek miękiszowych. Zarówno cechy włókien jak i komórek miękiszowych zależą od gatunku i warunków wzrostu drzewa. Przedstawione gatunki różnią się porowatością ścianek podłużnych komórek drewna wczesnego i późnego. Inaczej wyglądają jamki w ściankach komórek drewna sosnowego i otwory w ściankach drewna dębowego. W drewnie dębowym perforacja ścianek podłużnych jest na całym obwodzie - ryc. 3a, inaczej jak w drewnie sosnowym, gdzie jamki rozmieszczone sa symetrycznie po obu stronach podłużnych komórek. Do materiałów, które współcześnie powszechnie stosujemy w wielowarstwowych przegrodach budowlanych połączonych z drewnem, należą włókniste materiały termoizolacyjne. Do analizy wybrano wełnę z włókien drzewnych, reprezentującą materiały o porowatej budowie włókien i wełnę szklaną jako reprezentującą materiały o pełnej budowie włókien, nie wchłaniających wilgoci.

Na ryc. 4 przedstawiono fotografie mikroskopowe zbadanych materiałów izolacyjnych: maty z włókien drzewnych i maty z włókien szklanych.

Wełna szklana (podobnie jak wełna mineralna) w powiększeniu mikroskopowym to cienkie włókna, o pełnym przekroju, nie wchłaniające wilgoci - ryc. 4d. Jeżeli nasycenie parą jest wysokie to wilgoć skrapla się grawitacyjnie pomiędzy włóknami. Zasadnicza różnica pomiędzy izolacją z wełny mineralnej i waty szklanej, a nasiąkliwymi włóknami drzewnymi - fig 4a, b, polega na budowie włókien tych materiałów. W izolacji z włókien drzewnych, wilgoć wchłaniana jest całą objętością włókien. Włókna tych materiałów są higroskopijne. Po zamoknięciu izolacji w pierwszej kolejności wilgoć chłoną włókna. Ta właściwość wiórów drewnianych i innych włókien porowatych występujących w innych materiałach termoizolacyjnych, powoduje, że w przypadku izolowanych nimi wielowarstwowych przegród, odprowadzenie pary wodnej, podobnie jak jej chłonięcie, będzie zdecydowanie bardziej skuteczne jak w materiałach zbudowanych z włókien niehigroskopijnych.

Jeżeli wilgoć nie zostanie wchłonięta we włókna materiału termoizolacyjnego będzie gromadzić się początkowo na powierzchni, później zacznie opadać grawitacyjnie w matach, gromadzić się w porach pomiędzy włóknami, a wreszcie opadać grawitacyjnie i przenikać do masy drewna.

Mechanizm rozchodzenia wody z kropli znajdującej się na macie drzewnej i szklanej pokazano na ryc. 5a, b. Włókno z wełny drzewnej zawilgoconej kroplą wody pokazano na Ryc. 5a w przekroju podłużnym. Woda została wchłonięta przez włókna i jedno z włókien pokazano w przekroju podłużnym na ryc. 5a. Wchłonięta woda widoczna jest w postaci kilku kropli. W otoczeniu włókna woda nie występuje. Na ryc. 5b pokazana jest kropla wody utrzymująca się na włóknach z maty szklanej. Czerwonym prostokątem zaznaczono strugę wody opadającej grawitacyjnie. Jeżeli woda opada gromadzi się w porach pomiędzy włóknami usuwając powietrze materiał izolacyjny zmienia swoje własności. Gdy woda opada grawitacyjnie na element z drewna, inicjowane są procesy korozji biologicznej niszczące drewno. Podobne procesy zawilgocenia przebiega w próbkach z wełny mineralnej, która także zbudowana jest z włókien o jednolitych i pełnych przekrojach. 


\section{DYSKUSJA}

Wpływ zawilgocenia, temperatury i czynników technologii zabezpieczania na trwałość drewna, badało wielu badaczy. W pracy (Bednarek Z.,i in. 2004) opisano metody i skutki oddziaływania na drewno preparatami solnymi. Drewno badano po impregnacji próżniowo - ciśnieniowej w temperaturach $20^{\circ} \mathrm{C}, 50^{\circ} \mathrm{C}, 100^{\circ} \mathrm{C}, 150^{\circ} \mathrm{C}, 200^{\circ} \mathrm{C}, 230^{\circ} \mathrm{C}$. Próbki badano statycznie i dynamicznie. W badaniach statycznych przeprowadzono badania: na zginanie, na ściskanie wzdłuż włókien, na ściskanie w poprzek włókien, na rozciąganie wzdłuż włókien. W badaniach dynamicznych sprawdzono wytrzymałość na zginanie dynamiczne i udarność drewna. Wykazano, że stosowanie metod impregnacji próżniowo ciśnieniowej preparatem solnym zmniejsza wytrzymałość próbek drewna impregnowanych w stosunku do próbek nie impregnowanych. Autorzy wyjaśniają, że jest to związane z naruszeniem struktury drewna na skutek oddziaływania za pomocą roztworu wodnego soli w impregnacie, zmian ciśnienia i podciśnienia podczas nasączania substancją impregnującą.

W pracy doktorskiej (Jarosz M. 2020) przeanalizowano zastosowanie materiałów termoizolacyjnych w termomodernizacji obiektów zabytkowych z drewna w rejonie Sudetów. Zbadano wielowarstwowe przegrody zewnętrzne budynków modernizowanych z zastosowaniem występujących na rynku materiałów izolacyjnych $w$ tym wełny mineralnej. Pokazano rozmaite warunki i skutki ich stosowania. Pomimo szerokiej analizy nie sformułowano kryterium, według którego można dokonać wyboru termoizolacji do ocieplania obiektów z drewna.

W pracy ( Trochonowicz M. i in. 2013) przeanalizowano i policzono zmiany wartości współczynnika przewodzenia ciepła $\lambda$ materiałów termoizolacyjnych wbudowanych wewnątrz pomieszczeń. $\mathrm{Na}$ ryc. 7 zacytowano wykres z pracy ( Badger S. 2017).

Z wykresów pokazanych na ryc. 6 wynika, że wraz ze wzrostem temperatury i zawilgocenia materiałów termoizolacyjnych wzrasta współczynnik przewodzenia ciepła $\lambda$.

Temat wzrostu wartości współczynnika przewodzenia ciepła $\lambda$ wraz ze wzrostem ilości wody w porach pomiędzy włóknami materiałów izolacyjnych zajmował się (Badger S., 2017). W pracy zwrócono uwagę, że aby izolacja była skuteczna musi być sucha. Badane próbki izolacji wykonano w postaci płytek i pokazano na ryc. 7. Próbki poddano działaniu pary przez wystawienie powierzchni o wymiarach 8 cali $\times 8$ cali na działanie wody o temperaturze $50 \mathrm{C}$ i różnicy temperatury $\Delta \mathrm{T}=1^{\circ} \mathrm{C}$ na przeciwległych powierzchniach. Próbki nie były obracane podczas badań. Przewodność cieplna próbek została określona metodą opisaną w normie ASTM C518.

Już po czterech dniach nastąpił znaczący wzrost masy i współczynnika przewodzenia ciepła wełny mineralnej, co pokazano na wykresie - ryc. 7b). Jeżeli nastąpił wzrost masy wełny mineralnej to wilgoć zgromadziła się w porach pomiędzy włóknami, ponieważ włókna są nie nasiąkliwe. W macie nastąpiło zmniejszenie ilości przestrzeni wypełnionych powietrzem. Warto tutaj przypomnieć, że przewodność cieplną powietrza ilustruje współczynnik $\lambda=0,025\left[\frac{W}{m \times K}\right]$, a wody $\lambda=0,6\left[\frac{W}{m \times K}\right]$. Współczynnik przewodzenia wody jest prawie ( 24 razy) dwudziestoczterokrotnie wyższy od przewodności cieplnej powietrza. Materiał termoizolacyjny włóknisty, o włóknach nie nasiąkliwych, na skutek zawilgocenia z izolatora staje się przewodnikiem. Straty ciepła w budynkach izolowanych wełną mineralną powiększają się, a na ścianach od strony wnętrza wykrapla się wilgoć i rozwija się korozja biologiczna. Procesy te są szczególnie destrukcyjne dla drewna.

Następstwem obecności wody zamiast powietrza w porach pomiędzy włóknami w matach złożonych z pełnych, niehigroskopijnych włókien jest zmiana właściwości izolacyjnych. Przy wzroście współczynnika przewodzenia ciepła $\lambda$ maleje opór cieplny materiału $R=\frac{1}{\lambda} \mathrm{i}$ maleje izolacyjność cieplna przegrody. Zawilgocona wata szklana $\mathbf{i}$ wełna mineralna staje się przewodnikiem, a nie izolatorem.

W materiałach termoizolacyjnych złożonych z włókien porowatych, wilgoć wchłonięta w porowate włókna nie powoduje znacznej utraty właściwości termicznych izolacji, ponieważ przestrzenie pomiędzy włókami są wypełnione powietrzem, a ciągła wentylacja w warstwie izolacji powoduje usu- 
nięcie wilgoci z przestrzeni pomiędzy włóknami. W każdym materiale izolacyjnym wartość współczynnika przewodzenia ciepła $\lambda$ zależy od ilości porów z powietrzem. Im większa jest ilość porów z powietrzem pomiędzy włóknami, tym niższy, czyli lepszy jest współczynnik $\lambda$, a materiał termoizolacyjny ma większy opór cieplny $\mathrm{R}$ i jest izolatorem.

W zawilgoconym materiale izolacyjnym, w sąsiedztwie pożywki, którą jest drewno, następuje rozwój korozji biologicznej. Korozja biologiczna powoduje ubytki matrycy prowadzące do osłabienia zamocowania włókien drzewnych i globalnego zmniejszenia nośności elementów z drewna co opisano w pracach ( Kowal Z., 1996) i ( Misztal B., 2018).

W pracy (Tarkowski S., i in. 2002) omówiono zagrożenia dla zdrowia związane ze stosowaniem pełnych włókien mineralnych, a zwłaszcza mineralnej wełny izolacyjnej. Zgodnie z dyrektywą Unii Europejskiej 98/98/WE wełna mineralna została sklasyfikowana jako drażniąca w kategorii 3, (Tarkowski S., i in. 2002). W pracy nie omawia się t. zw. granulatu z wełny mineralnej stosowanego powszechnie w Polsce do ocieplania stropodachów. Jest to materiał luźny, wyjątkowo toksyczny, o zmiennych właściwościach termoizolacyjnych. Tak zwany granulat $z$ wełny mineralnej jest niekorzystny szczególnie w ocieplaniu konstrukcji drewnianych. Uzupełniając powyższe informacje należy dodać, że od czerwca 2000 r. w Niemczech obowiązuje zakaz obrotu, produkcji i wykorzystania bio-trwałych sztucznych włókien mineralnych w izolacji cieplnej i akustycznej budynków oraz w izolacjach technicznych (Tarkowski S., i in. 2002).

\section{WNIOSKI}

Budowa drewna powoduje, że wybór materiałów termoizolacyjnych w sąsiedztwie drewna w przegrodach budowlanych nie może być przypadkowy.

Wełna mineralna lub wata szklana wykonane są z surowców reklamowanych jako naturalne. W kontakcie $z$ drewnem jest to jednak okoliczność nie wystarczająca. Stosowanie w obecności drewna materiału izolacyjnego, utrzymującego wilgoć jest nieprawidłowe. Jednolite i nie porowate włókna szklane i mineralne nie mają zdolności wchłaniania wody. Wilgoć z otoczenia wypycha powietrze z przestrzeni pomiędzy włóknami i wypełnia je, zamieniając materiał izolacyjny w materiał przewodzący.

Porowata budowa włókien np. wełny drzewnej (ryc. 4a, c i ryc. 5a) powoduje, że materiał ma zdolność podciągania kapilarnego, gromadzenia wilgoci i powolnego jej uwalniania wraz ze spadkiem wilgoci otoczenia. Przy ciągłej wymianie powietrza w wielowarstwowej przegrodzie wydalanie nadmiaru wilgoci pomiędzy włóknami i z włókien jest skuteczne dzięki dużej powierzchni parowania porowatych włókien. Stosowanie w sąsiedztwie drewna, termoizolacji zbudowanej z włókien o porowatej budowie pochłaniających wilgoć wcześniej, zanim przedostanie się ona do drewnianego elementu konstrukcyjnego jest warunkiem koniecznym.

W materiałach izolacyjnych zbudowanych z porowatych włókien, woda w pierwszej kolejności zostaje wchłonięta przez włókna - fig $5 a$, pozostawiając przestrzenie pomiędzy włóknami wypełnione powietrzem. Dzięki możliwości wchłaniania pewnej części wilgoci przez włókna, pory pomiędzy włóknami są wypełnione powietrzem, mata zachowuje własności termoizolacyjne, a współczynnik przewodzenia ciepła $\lambda$ i opór cieplny $\boldsymbol{R}$ maty zmienia się nieznacznie.

Jako kryterium wyboru materiału termoizolacyjnego znajdującego się w bliskim sąsiedztwie drewna rekomenduje się materiały o stabilnym współczynniku przewodzenia ciepła $\lambda$ w przedziale naturalnych zmian wilgotności otoczenia, w którym znajdują się ocieplone przegrody budowlane z udziałem drewna. Wełna mineralna i wata szklana nie spełniają tego kryterium. 


\section{BIBLIOGRAPHY}

Badger S. Effects of Moisture on Thermal Insulation, prezentacja na konferencji IDEA 2017 Sustaining our Success 108th Annual Conference \& Trade, Show June 26-29

Bednarek z., Kaliszek-Wietecka A., Wytrzymałość drewna impregnowanego ogniochronnym środkiem solnym metodą próżniowo- ciśnieniową. 50 - ta Jubileuszowa Konferencja N.K.I.L.i W.PAN i K.N. PZTIB „Krynica 2004" 12-17 września 2004 roku.

Jarosz M. Forma i detal architektoniczny drewnianych budynków regionalnych w Sudetach, powstałych do 1945 roku, w odniesieniu do podwyższenia izolacyjności termicznej ich przegród zewnętrznych. Praca doktorska, Wydział Architektury, PWr., 2020

Kowal Z. Nośność krytyczna słupów drewnianych jako kompozytów włóknistych. Sympozjum - drewno i materiały drewnopochodne w konstrukcjach budowlanych. Szczecin-Międzyzdroje 05-06 września 1996 r.

Misztal B. Wooden Domes. History and Modern Times. ISBN 978-3-319-65740-0, Springer 2018.

Tarkowski S., Krajewski j. a., Materiały izolacyjne zawierające sztuczne włókna mineralne - zagrożenia, [w:] Nauka i Praktyka, 3/2002, Instytut Medycyny Pracy im. prof. Jerzego Nofera, s. 16-20

Trochonowicz M., Witek B., Chwiej M. Analiza wpływu wilgotności i temperatury powietrza na wartość współczynnika przewodności cieplnej $\lambda$ materiałów termoizolacyjnych stosowanych wewnątrz pomieszczeń. Budownictwo i Architektura 12(4) (2013) 165-176

\section{AUTHOR'S NOTE}

Barbara Misztal works at the Wroclaw University of Technology as a professor at the university, and is the author of dozens of scientific papers, including two books. At the same tame as a didactic and scientific work, she has developed several dozen author's projects, is a building appraiser and author of many studies.

Anna Mielińska author and co-author of architectural projects, member of the Chamber of Architects of the Republic of Poland. PhD student at the Faculty of Architecture of the Wrockaw University of Technology. Interests: sustainable architecture, electron microscopy

\section{O AUTORACH}

Barbara Misztal pracuje na Politechnice Wrocławskiej na stanowisku prof. uczelni, jest autorem kilkudziesięciu prac naukowych w tym dwóch książek. Równocześnie z pracą dydaktyczną i naukową wykonała kilkadziesiąt autorskich projektów, jest rzeczoznawcą budowlanym i autorem kilkudziesięciu ekspertyz.

Anna Mielińska autorka i współautorka projektów architektoniczno-budowlanych, członkini Izby Architektów RP. Doktorantka Wydziału Architektury Politechniki Wrocławskiej. Zainteresowania: architektura zrównoważona, mikroskopia elektronowa.

Contact | Kontakt: barbara.misztal@pwr.edu.pl; anna.mielinska@pwr.edu.pl 